\title{
REPORT ON 'NATIONHOOD IN THE CARPATHIAN REGION. HUNGARIANS AND THEIR NEIGHBORS - SOCIOLOGICAL PERSPECTIVES' - A JOINT CONFERENCE OF THE HUNGARIAN SOCIOLOGICAL ASSOCIATION AND THE HUNGARIAN DEPARTMENT OF SOCIOLOGY AND SOCIAL WORK OF BABEȘ-BOLYAI UNIVERSITY
}

\section{KINGA SZÉKELY ${ }^{l}$}

The annual conference of the Hungarian Sociological Association was held between 27-29 $9^{\text {th }}$ of November, 2014 in Kolozsvár (Cluj-Napoca), Romania. The topics of this conference were built around the concept of 'being Hungarian' and investigated nationhood and minority from a sociological perspective. The conference involved the Hungarian paradigm (which exists both within Hungary and outside its borders as well), thus it highlighted the importance of individual cultural background.

The conference was organized as an international forum for the discussion of the findings of sociological research that had been conducted in various countries.

There were three forms of formal discussion. Firstly, keynote lectures focused on the one hand on everyday life and nationhood, sociolinguistics in an inter-ethnic space, dual citizenship and national identity and ethnocentrism - as described by social scientists from the Carpathian Basin; on the other hand, the keynote speeches also focused on new methodological opportunities, highlighting the importance of a new paradigm that uses Big Data, and on the habits of 'good sociology', or sociological etiquette. Secondly, panel discussions were closely related to keynote lectures by topic. The strength of the panels was that they offered a forum for discussions and debates, thereby

1 Kinga Székely is a Ph.D. candidate at the Corvinus University of Budapest, e-mail: szkinga2003@gmail.com 
providing a place for interdisciplinary dialogue. Finally, sections provided researchers with the opportunity to present recent findings about related topics.

Beside the formal discussions, participants could also meet colleagues, sociologists and also economists in an informal environment during dinners and at the reception for the event. Participants of the conference also had the opportunity to get to know more about their prospects for publishing in a Hungarian-language context during books and journal introductions.

The topic of collective trauma warns us that we must account for our lives and face our past. Trauma and 'identity' are inseparable; the latter term can involve a deeper understanding of phenomena, while use of the former term is becoming increasingly fashionable in the literature. One concept of trauma was presented through the memory of a historical trauma (the Holocaust) in relation to the Roma experience, or more precisely, the Nazi genocide of the Roma. Analysis of this relationship was undertaken based on the accessible representations of memory (songs, films, interviews, art work and established practices). Another conception of trauma was presented in relation to bodies, secrets and taboos. The term trauma as originally used in a medicalpsychological environment has been adapted by social scientists and at the same time is often used in everyday life and thus it is no longer so narrowlydefined. In relation to the body it may be employed in the context of staged psychodrama encounters between victims and perpetrators of the Holocaust. This example shows how the interaction of trauma and history may contribute to the process of healing.

While during the conference it was possible on the one hand to participate in discussions in sections that focused on the minority-majority content of topics - such as inter-ethnic relations, identity and economic cooperation, migration, education, elites and ethnicities, political socialization, and religions -, on the other hand, urban problems and the restructuring of rural areas were also discussed. Another major topic was inequalities, involving an economic, social and/or gender perspective at the local and global level. Another major topic of discussion concerned the opportunities and dangers inherent in using the communication technology of the $21^{\text {st }}$ century; namely, digital society. Further presentations concentrated on the relationship between youth and sport, and deviances and prevention.

In the framework of globalization and Europeanization ethno-linguistic minorities in the Carpathian Region have become more mobile and interconnected in a broader sense as they can interact with political, cultural, and socio-economic global networks (both Hungarians, and Non-Hungarians) that affect their local relations. 
New transnational regulations have changed the "opportunity structure" of ethnic Hungarians in Romania in political and economic terms as well. This change is resulting in more ethnic cooperation in the economy and increases the presence of ethno-linguistic diversity which has intrinsic value. Economic diversity was presented along the lines of a cost - benefit appraisal based on new institutionalism and new economic sociology. It seems that one key to success may be maintaining the balance between coupling and decoupling from the majority.

The ethno-national identity of Hungarian minorities who live in Romania, Serbia, Slovakia and Ukraine (including their relationship with Hungarians living in Hungary) based on empirical results from the last Kárpát-Panel study show that they are part of the 'unitary' cross-border pan-Hungarian nation. But this form of identification is less important than regional 'Hungarianness' in the minority identity of those who live outside the borders of Hungary. Regarding identification with the majority community, results indicate that Hungarian minorities who are living in the aforementioned countries become integrated into the majority nation at different levels from the perspective of citizenship community - Hungarians from Serbia the least, and Hungarians from Romania the most - according to their perception of their minority situation and experiences with discrimination.

In Linguistic Landscapes empirical findings that resulted from the analysis of the relationship between space, identity and language showed that the sphere of public signs generates the most conflicts, rather than the context of cultural reproduction, or the context of administrative communication. Placenaming and marking signals mean recognition or exclusion, dominance or relative symmetry.

In the creation of ethnic identity and locality the reflexive maintenance of local and ethnic identity-based cultural resources (language, forms of socialization, marital patterns, economic attitude and microeconomic history) were shown to be important in processes of economic adaptation and integration, as illustrated through the example of a German village in Hungary.

Ethnographic research from Szeklerland stresses the importance of cooperation ('kaláka': traditional, reciprocal forms of work, work parties or work bees). The formation and functioning of cooperation depends not only on European and national regulations but also on ethnic/minority struggles. The cooperatives (re)launched in 2012 (as an ethnic initiative) pay heed to two significant historical experiences: one, the success of the cooperatives that existed before the Second World War; the second, the failure of and negative experience with the cooperatives that occurred under state socialism. 
These discursive strategies shape willingness to cooperate.

Topics that concerned Emigration from Hungary and from neighboring countries concentrated on the main characteristics of emigration in different regions, such as type, direction and intensity and composition of migrants using panel data, thereby making it possible to identify changes over time interconnected with the demographic, economic and labor market processes of the particular country.

In the section on Education a study into the preparedness of Early-Career Caregiver Graduates from Cluj-Napoca (Kolozsvár, Romania) and Eger (Hungary) was motivated by the desire to better fit education to labor market expectations, thus smoothing the transition of graduates into the labor market. A study about the importance of Romanian language competence in the career success of Hungarian Social Work graduates found that Romanian language competences play an important role in the career success of Hungarian ethnic graduates. Another study described the motivation for individuals to enter higher education. This study found support for the notion that social reproduction within a family acts upon the educational choices of prospective students. Beside human capital factors, psycho-sociological motivations were presented in this context. A study into the motivation of Hungarian minority parents for choosing majority language schools for their children argued that - through testing the scholastic performance of Subcarpathian (Ukrainian) Hungarians in a case study from Beregszász/Berehovo - shifting the language of instruction between school levels significantly negatively impacts school performance. Another finding showed that ethnically based background factors are less important, while ethnically-neutral factors such as gender, age, parents' qualifications and occupation and home learning environment are significant determinants of performance.

The forum on Political Socialization analyzed through empirical studies youth civic and political socialization by presenting agents, processes, outcomes, differences and similarities between countries, with a primary focus on Hungary and its neighboring countries.

Religion can work as an integrative force, but can also be a source of conflict in the case of religious diversity. This section included studies in which religion, religiosity or non-religiousness were investigated in the case of different nationalities in relation to volunteering, school performance, motivation and national identity.

The inclusion of a section on Elites and Ethnicity was motivated by the fact that we live in multi-ethnic states where the elite is not recruited only from the majority, but ethnic-minorities play also an important role in forming elites in cultural, religious, intellectual, economic and political setting. In this section 
information was presented about the ethnic background of reputational elites (i.e. people who are listed in national encyclopedias and 'Who's who' books of the last century).

In the section on Urban Problems the territorial components of social inequality were described using the example of Cluj-Napoca (Kolozsvár). Related to Budapest conflicts focused on changes in the typical use of traditional inner city areas, on urban newcomers in villages surrounding Budapest, and on street musicians. Urban-rural differences in Hungary were discussed in relation to neighborhood satisfaction and involved the components of trust, happiness and subjective well-being.

In the section on Restructuring Rural Areas papers focused on social changes in rural areas of the Carpathian Basin such as agricultural restructuring, rural development and social well-being and their effects on territorial processes and local communities.

In Social Dimensions of Economic Transformation details were presented about the economic changes of the last decades which have had a significant impact on Central and Eastern European societies. In this section speakers described the motivation and the behavior of economic actors and the importance of social networks in economic activities, results and institutions in this changing environment.

Social Inequalities included a discussion about exclusion (spatial), marginalization, segregation of Roma settlements, school segregation and boundaries between Roma and Non-Roma Neighborhoods, as well as inclusionary and exclusionary practices in local development programs.

Family and Gender-related topics were also covered in relation to social inequalities. In this section papers focused on the following question: how do social inequalities shape family patterns, parental roles and childrearing practices (with a special focus on child poverty)? Here, the recent trend towards gender equality inside and outside the family (involving the role of part-time work, cohabitation, and the social meaning of childlessness) was discussed.

The performance of and changes in communication technology were the focal points of the digital society section which considered both the effect of changes on the present and on future social life. Digital society involves the creation of new forms of social relations which require that analysis of this segment of society be methodologically reformed. The importance of Big Data in a virtual environment was one major highlight of the discussion which addressed the question of how to assist participants to better use online databases in order to accurately describe users and their attitudes. Finally, the dangers and uncertainties of being a part of digital society were described. 
The section Youth and Sport focused on social problems and conflicts as represented in public sport discourses and detailed the effects of sexual education in the family on youngsters. The role of football was a primary focus of the theoretical and methodological discussions.

The section Deviances and Prevention focused on the important role of interpersonal relationships in (re)integrating deviants from disadvantaged backgrounds. Most of the studies that were presented concentrated on analyzing the deviation prevention programs used in schools among youth (through a dynamic professional team named Independence Zone), and in other contexts.

A major strength of the conference was that besides being an international forum for discussion of the results of sociological research in relation to ethnicity, identity and minority content, it provided a good space for both transnational and trans-generational dialogue within and between subfields of sociology. 